\title{
Physiological effect of Selenium\& Green tea treatment on Cisplatin-induced Nephrotoxicity in Rats
}

\author{
Hewaida A.E.Fadel \\ Ph.D Lecturer of Physiology
}

Department of Nutritional Chemistry\& Metabolism, National Nutrition `Institute

\begin{abstract}
:
7 he present study was a trial to investigate the physiological effect of Selenium\& Green tea as natural antioxidant on cisplatin- induced nephrotoxicity in rates. Thirty two adult male albino rats (Sprague Dawley) were divided into two main groups. First group: 8 rats were fed on standard diet (S.D.), as a negative control group. Second group: 24 rats were injected with a single dose of Cisplatin (CP) for inducing nephrotoxicity $(2.5$ $\mathrm{mg} / \mathrm{Kg} \mathrm{BW}$ ) then it was divided to three subgroups (8 rats/ subgroup). Subgroup (1): fed on (S.D.) as a positive control group (nephrotoxic group). Subgroup (2): fed on (S.D.) + Selenium (0.6 mg/Kg BW/day).Subgroup (3): fed on (S.D.) +Green Tea (100 mg / kg BW/day). The experimental period was four weeks. The results proved that selenium\& green tea groups showed significant increase in body weight gain (BWG) and food efficiency ratio (FER) when compared with nephrotoxic group. Rats treated with Selenium and Green tea showed significant increase in antioxidant level: serum vitamin $E$ \& kidney glutathione when compared with nephrotoxic group. The results showed that Selenium and Green tea groups showed significant reduction in kidney function indices: serum urea, creatinine, uric acid, nitric oxide and serum sodium in compared with nephrotoxic group. Best results in histopathological examination of kidney were in Selenium group. Conclusion: These results suggest that the use of selenium\& green tea could be beneficial in improving kidney functions in nephrotoxic rats, through a significant decrease in peroxidative levels and increase in antioxidant status.
\end{abstract}

Key words: Selenium- Green Tea- Natural antioxidants - CisplatinNephrotoxicity - Histopathological examination - Kidney function 


\section{INTRODUCTION}

The kidneys are the main organs of the body through which nitrogenous wastes are excrete in the form of urea. The basic functional unit of the kidneys is the nephron. Most kidney diseases attack the nephrons, causing them to lose their filtering capacity (Bruce, 2004). Various environmental agents such as (chemical pesticides, solvents and similar materials), animal venom, certain plants and some drugs are nephrotoxic by producing free radicals such as $(\mathrm{O} 2, \mathrm{RO} 2$, $\mathrm{OH}, \mathrm{NO} 2, \mathrm{NO}$ ) which can cause kidney damage and dysfunction by starting chain reactions that damage cells (Staci Nix, 2005).

Cisplatin (CP, cisdiamminedichloroplatinum(II)) is an antineoplastic drug used in the treatment of many solidorgan cancers, but nephrotoxicity limits its clinical use. (Miller et al, 2010). Cisplatin therapy has been demonstrated to induce oxidative stress, principally involving reactive oxygen species (ROS), in renal tubular cells. The interaction of ROS with cellular components may result in damage to DNA, proteins, and lipids. Excessive ROS generation caused by cisplatin may overwhelm the natural antioxidant defenses of the kidney cells and lead to lipid peroxidation and delayed-onset kidney injury (Yi et al, 2011).

\section{Antioxidants} are molecules capable of slowing or preventing that chain reactions by removing free radicals intermediates and inhibit other oxidation reactions by being oxidize themselves (Bjelakovie, 2007). Moreover, Saravanan and Nalini, (2007) demonstrated that treatment with antioxidants offers protection against free radical-mediated oxidative stress in kidney of animals with nephrotoxicity.

Green tea (Camellia sinensis L.) contains strong antioxidative flavonoids (polyphenol). The polyphenol type of tannins and catechins were (epicatechin, epicatechin3-gallate, epigallocatechin and epigallocatechin-3-gallate (EGCG)). EGCG has been reported to have a preventive 
and treatment effects on several types of chronic diseases (Lambert \& Elias, 2010). Green tea flavonoids (polyphenols) contain carotenoids, tochopherols, ascorbic acid, minerals such as chromium, manganese, selenium or zinc and certain phytochemical compounds. It is a more potent antioxidant than black tea (Scalbert\& Wiliams, 2005). Flavonoids that are contained in a plant have been known to have several physiological activities including anti-inflammative and antioxidative activities (Tsao, 2010).

Selenium is an essential element for antioxidant reactions in humans and animals and an important component of several major metabolic pathways, including synthesis of thyroid hormone metabolism, antioxidant defense systems and immune functions (Gandhi et al. 2013). Dietary selenium comes from nuts, cereals, meat, fish and eggs (Zhang et al., 2008). Selenium salts are toxic in large amounts, but trace amounts of the element are necessary for cellular function in most, forming the active center of the glutathione peroxidases and thioredoxin reductase (Wang, et al., 2007).

Aim of the study: The present study was a trial for investigating the physiological effect of treatment with Selenium\& Green tea as natural antioxidant on cisplatin- induced nephrotoxicity in rates.

\section{MATERIALS \& METHODS}

Thirty tow adult male Sprague - Dawley albino rats weight (150-200 g) allowed free access to water and standard diet (S.D.) which was prepared according to modified AIN-93-A (Reeves et al.,1993) for four days, all rats were individually weighed at the start of the experiment. The rats were divided into two groups. First group: 8 rats were fed on standard diet (S.D.), as a negative control group. Second group: 24 rats were injected intraperitonial with a single dose of Cisplatin (CP) for inducing (nephrotoxicity) $\quad(2.5 \quad \mathrm{mg} / \mathrm{Kg}$ BW.) was dissolved in physiological saline solution 
within one hour before injecting according to (Iseri et al., 2008) then it was divided to four subgroups each one contained 8 rats. Subgroup (1): fed on (S.D.), as a positive control group (nephrotoxic group). Subgroup (2): fed on (S.D.) + Selenium as Sodium Selenite $\left(\mathrm{Na}_{2} \mathrm{SeO}_{3}\right)$ $(0.6 \mathrm{mg} / \mathrm{BW} /$ day) according to (Chattopadhyay et al., 2003). Subgroup (3): fed on (S.D.) + Green tea (leaves powder) (100 $\mathrm{mg}$. $/ \mathrm{kg} \mathrm{BW} /$ day) according to (Yokozawa et al., 2005).The experimental period was four weeks. At the end of the experimental period, rats were sacrificed under ether anesthesia. Fasting blood samples were collected from portal vein. Serum was separated and frozen at -20 for biochemical analyses.

Biological Evaluation: Food Intake: The total diet consumed per group during the period of the experiment was calculated. -Body weight gain was calculated as follow: Body weight gain $(\mathrm{g})=$ final weight $(\mathrm{g})$ - initial weight $(\mathrm{g})$.

After animal sacrificed the internal organ (kidney) was removed and washed in saline.
The kidneys were kept in $10 \%$ formalin for the histological study, described by (Janebova and Zima, 1997). Food Efficiency Ratio (FER) was calculated as mentioned by (Hosoya, 1980).

Antioxidants level:

Determination of Serum Vitamin E Concentration was determined by HPLC as described by (Janebova and Zima, 1997) and Kidney Glutathione Content (GSH) by (Beutler et al, 1963). Kidney function tests: Determination of serum Urea Nitrogen, Creatinine, Uric acid, Nitric Oxide, Sodium, Potassium, Total Protein\& Albumin were determined by methods described by (Tietz,1990), (Tietz,1986), (Tietz,1990), (Muntogomry\&Dymock,1961), (Trinder,1951), (Sunderman and Sunderman,1958), (Tietz,1994)\& (Tietz,1990) respectively .

Histological examination of kidney was carried out according to the (Drury and Wsllington, 1980) in Faculty of Veterinary, Cairo University, Egypt. The results were 
Hewaida A.E.Fadel

analyzed statistically using SPSS/PC program V17 (2008) .T-test and ANOVA were applied in this study for comparison among mean of different groups according to the method described by (Kurtz,1983).

\section{RESULTS:}

Table (1) showed that the nephrotoxic rats exhibited significant decrease in food intake, body weight gain and food efficiency ratio (FER) at $(\mathrm{P}<0.05)$ as compared with a control group. Nephrotoxic groups treated with Selenium\& Green Tea and revealed a significant decrease at $(\mathrm{P}<0.05)$ in food intake, body weight gain and food efficiency ratio (FER) when compared with the control group and a significant increase at $(\mathrm{P}<0.05)$ compared with nephrotoxic group.

Table (2) showed that nephrotoxic group exhibited a significantly reduction in serum vitamin $\mathrm{E}$ concentration and kidney tissue glutathione content at $(\mathrm{P}<0.05)$ when compared with a control group. Selenium\& Green Tea treated groups showed a significantly increase for selenium group\& significantly reduction for green tea group in serum vitamin $\mathrm{E}$ concentration at $(\mathrm{P}<0.05)$ and significantly increase in kidney tissue glutathione content at $(\mathrm{P}<0.05)$ for both groups when compared with a control group and also with nephrotoxic group. While, these groups showed a highly significantly increase in serum vitamin $\mathrm{E}$ at $(\mathrm{P}<0.05)$ and a highly significant increase in kidney glutathione content at $(\mathrm{P}<0.05)$ when compared with nephrotoxic group.

Table (3) showed that serum urea nitrogen, creatinine, serum uric acid and nitric oxide levels in the nephrotoxic group were a significantly elevate at $(\mathrm{P}<0.05)$ when compared with the negative control group. Nephrotoxic rats supplemented with selenium\& green tea showed a significantly increase in serum urea nitrogen, creatinine, serum uric acid and nitric oxide levels at $(\mathrm{P}<0.05)$ when compared with the negative control group. While in comparing with nephrotoxic group showed a significantly 
reduction in these levels at $(\mathrm{P}<0.05)$.

Table (4) showed that serum Sodium level in the nephrotoxic group showed a highly significant elevate at $(\mathrm{P}<0.05)$ and a significant reduction in serum Potassium at $(\mathrm{P}<0.05)$ when compared with the negative control group. Selenium\& Green Tea groups showed a significant increase in serum Sodium at $(\mathrm{P}<0.05)$ and a significant decrease in serum Potassium at $(\mathrm{P}<0.05) \quad$ when compared with the control group. While in comparing with nephrotoxic group showed a significantly reduction in serum Sodium at $(\mathrm{P}<0.05)$ and a significant increase in serum Potassium at $(\mathrm{P}<0.05)$.

Data from the same table showed in the nephrotoxic group a significant reduction in serum Total Protein\& Albumin at $(\mathrm{P}<0.01)$ when compared with the control group. Selenium\& green tea groups showed a significant decrease in serum Total Protein\& Albumin at $(\mathrm{P}<0.05)$ when compared with the negative control group. While, in comparing with nephrotoxic group showed a significantly increase in serum Protein\& Albumin at $(\mathrm{P}<0.05)$ when compared with the nephrotoxic group.

\section{Histopathological results:}

Photo (1) Showed normal histological structure of renal parenchyma in control group. Meanwhile, as cleared in Photo (2) Kidney of rats from nephrotoxic group showed vacuolations of epithelial lining renal tubules in the renal cortex. There was a congestion of glomerular tufts, deposition of protein cast in the bowman's space and in the lumen of renal tubules. From Photo (3) there was presence of eosinophilic protein cast in the lumen of renal tubules as well as per tubular leucocytic cells infiltration. In addition, a cystic dilatation of renal tubules, As showed in Photo (4\&5) rat's kidney from selenium group revealed no histopathological changes. As cleared in Fig. (6), rat's kidney from green tea group revealed normal renal parenchyma. While, Photo (7) Showed that some of the same group revealed 
protein cast in the lumen of some renal tubules and few peri tubular leucocytic cells infiltration.

\section{DISCUSSION:}

The obtained results of nephrotoxic rats exhibited significant decrease in food intake, Body Weight Gain\& Food Efficiency Ratio (FER). These results are agreement with (Aaron et al., 2004) who cleared that food intake, body weight gain and (FER) were significant lower in Sprague-Dawley rats with repeated administration of Puromycin Amino nucleoside. Selenium\& Green Tea groups revealed a significant decrease in food intakes, body weight gain\& (FER) compared with a negative control group and a significant increase when compared with nephrotoxic group. These results appear to be in the line with (Macfarquhar, et al., 2010) who concluded that Selenium an element necessary for more normal cellular function, but it can has negative side effects included diarrhea, fatigue and nausea which resulted in reduction in food intake. Also with (Barbara, et al., 2005) who demonstrated that Cyclosporine A-induced nephrotoxicity significantly reduce the food intake. Treatment rats with tea polyphone exhibited significant increase in food intake and body weight gain when compared with nephrotoxicity rats.

$$
\text { Antioxidant Levels: }
$$

Glutathione has been called the "master antioxidant," in addition to its own potent antioxidant powers glutathione helps to recycle other antioxidants such as vitamins $\mathrm{C}$ and $\mathrm{E}$. Thus, glutathione can help to protect against cancer and other diseases caused by oxidative damage. Glutathione also plays an important role in the regulation of immune cells, and is a potent detoxifying agent. Low levels of glutathione have been associated with hepatic dysfunction, kidney dysfunction, immune dysfunction and cardiac disease (Pompella, et al., 2003).

The present results in table(3) were in the line with (Saad et aL, 2007) who demonstrated that serum vitamin $\mathrm{E}$ and kidney glutathione content 
were significant reduce at $(\mathrm{P}<0.01)$ in group of nephrotoxic rats injected with Cisplatininducing nephrotoxicity when compared with control group. In the same time, the results were in agreement with (Duru $\boldsymbol{e t} \boldsymbol{a L}$, 2008) who demonstrated that there were a significant reduction in serum vitamin $\mathrm{E}$ and kidney glutathione content at $(\mathrm{P}<0.05)$ in rats injected with Cyclosporine A (CSA) for inducing nephrotoxicity when compared with control group.

Kidney

Function: Blood Urea Nitrogen (BUN) test is a measure of the amount of nitrogen in the blood in the form of urea. Urea is a substance secreted by the liver, and removed from the blood by the kidneys. The liver produces urea in the urea cycle as a waste product of the digestion of protein. BUN generally indicates a degree of renal failure (Deepak, et al., 2008). Creatinine is a break down product of creatine phosphate in muscle. It is filtered out of the body by the kidneys into the urine. There is little to no tubular reabsorption of creatinine. If the filtering of the kidney is deficient, blood levels rise. A rise in blood creatinine levels is observed only with marked damage to functioning nephrons (Gross, et al., 2005).

The present study results table (4) was in agreement with Fatima et al., (2007) reported that intraperitoneal injection of $\mathrm{CP}$ can increase the serum creatinine and BUN amounts. Also, Ahn et al., (2014) \& Khan et al., (2009) reported an increment of serum creatinine and BUN amount by the administration of $\mathrm{CP}$, but reported a significant decrement of creatinine and BUN amount by the combined administration of $\mathrm{CP}$ and green tea extracts and stated the presence of effects of renal inhibitory damages by green tea extracts.

Uric acid is produced by xanthine oxidase from xanthine and hypoxanthine, which are produced from purine. Uric acid is more toxic to tissues than either xanthine or hypoxanthine. In human uric acid is the final oxidation product of purine metabolism and is excreting in urine (Aringer \& Graessler, 
2008). In addition, Frank, et al., (2008) mentioned that nitric oxide (NO) is synthesized in the biological system by the enzyme nitric oxide synthase (NOS). The final products of $\mathrm{NO}$ in vivo are nitrite\& nitrate. Appropriate levels of NO production are important in protecting an organ such as the liver from ischemic damage. However, sustained levels of NO production result in direct tissue toxicity. Elevate levels of serum nitric oxide occurs as a result of chronic renal disease.

The results of present study are in the line with (Duru, et aI., 2008) who demonstrated that there were significant elevation in serum uric acid and nitric oxide levels $(\mathrm{P}<0.0$ 1) in rats injected with Cyclosporine A for inducing nephrotoxicity when compared with control group. These results are partially agree with Yanardag, et aI., (2007) who reported that combination of Vitamin C, Vitamin $\mathrm{E}$ and Selenium reversed the increased levels of serum uric acid resulted in Ethanol-induced kidney injury in rats. Also the results are partially agree with (Yokozawa, et aI., 2005) who cleared that treatment rats with Green tea polyphenol showed significantly decrease serum nitrite and nitrate at $(\mathrm{P}<0.05)$, indicating that green tea polyphenol ameliorated renal failure induced by excessive dietary Arginine by decreasing NO productions. As well as, the results are agree with (Mohamadin, et aI., 2005) who stated that rats received different concentrations of Green tea extract as their sole source of drinking water, 4 days before and 21 day concurrently with Cyclosporine A(CsA) showed significantly reduction in uric acid at $(\mathrm{P}<0.05)$ comparing with CsA group.

In this respect Irmants, et aI., (2004) mentioned that electrolytes are salts that conduct electricity and are found in the body fluid, tissue, and blood. Sodium $(\mathrm{Na}+)$ is concentrated in the extracellular fluid (ECF) and potassium $(\mathrm{K}+)$ is concentrated in the intracellular fluid (ICF). The kidneys regulate fluid absorption, excretion and maintain a narrow range of electrolyte fluctuation. 
Normally, sodium and potassium are filtered and excreted in the urine and feces according to the body's needs. Electrolytes imbalance is associated with kidney disease such as nephrotic syndrome and acute renal failure. The results are in agreement with (Stojiljkovic, et aI., 2009) who demonstrated that there were a significant elevation in serum sodium at $(\mathrm{P}<0.05) \quad$ and significant reduction in serum potassium at $(\mathrm{P}<0.05)$ in nephrotoxicity rats when compared with control group.

\section{Histopathological examination:}

The present study results are in the line with Atessahin et al.,(2007) who reported that the administration of $\mathrm{CP}$ stimulated the tubular dilation and increased the renal necrosis. Also, Ahn, et al., (2014) reported that the pre Green tea polyphenol administered $\mathrm{CP}$ administered group revealed the reduction of microtubular dilation and necrosis compared to the $\mathrm{CP}$ administered group. These results are agree with Veljković, et al., (2016) who found that coadministration of green tea with gentamicin histologically showed renoprotective effect. BenAmara et al., (2011) Methimazole-treated rat kidneys exhibited leucocyte infiltrations, vascular congestion and narrowed Bowman's space. Coadministration of selenium through diet improved all the parameters cited above in adult rats and their progeny. Nevertheless, the distorted histoarchitecture in rat kidney was alleviated by selenium treatment.

\section{CONCLUSION:}

These results suggest that the use of selenium\& green tea could be beneficial in improving kidney functions in nephrotoxic rats, through a significant decrease of peroxidative levels and increase in antioxidant status.

\section{REFERENCES:}

Aaron E; Gary F; Chery S; Kevin E; Jean L $O$ and Chris B (2004): Protection against 
Puromycin Amino

Nucleoside - induced

Chronic Renal Disease in

the Wistar-Furth Rat.

Am. J. Physiol. Renal

Physiol. March. 287:

F81-F89.

Ahn TG; Kim HK; Park SW; Kim SO; Lee BR and Han SJ (2014):

Protective effects of green tea polyphenol against cisplatin-induced nephrotoxicity in rats. Obstet Gynecol Sci. 57(6): 464-470.

Aringer $M$ and Graessler $J$ (2008): Understanding Deficient Elimination of Uric Acid. Lancet. 372 (9654): 1929-1930.

Atessahin A; Ceribasi AO; Yuce A; Bulmus $O$ and Cikim G (2007): Role of ellagic acid against cisplatin-induced nephrotoxicity and oxidative stress in rats. Basic Clin Pharmacol Toxicol.100:121-126.
Barbara B; Olga $P$ and Stanislava K (2005): Provinol prevents CsAinduced Nephtotoxicity by reducing reactive oxygen species, iNOS, and NF-kB Expression. J. Histochemistry and Cytochemistry. 53(12):1459-1468

Ben-Amara; Troudi A; Garoui E; Hakim A; Boudawara T; Zeghal K and Zeghal N(2011):

Protective effects of selenium on methimazole nephrotoxicity in adult rats and their offspring. Experimental and Toxicologic Pathology. 63(Issue 6): 553-561.

Beutler E; Duron $O$ and Kelly B M (1963):

Improved method for the determination of blood glutathione. J. Lab. Clin. Med. 61: 882-888.

Bjelakovic G (2007):

Mortality in randomized trials of antioxidant. Supplements for primary 
Physiological effect of Selenium\& Green tea treatment on Cisplatin-induced

and secondary

prevention: Systematic review and Metaanalysis. J. AMA. 297

(8): 842-57.

Bruce MC (2004):

Human embryology and developmental Biology. Third edition. Saint Louis. Mosby Elsevier.

Chattopadhyay S; Palghosh S and Ghosh D (2003):

Effect of Dietary CoAdministration of sodium Selenite On Sodium ArseniteInduced Ovarian And Uterine Disorders In Mature Albino Rats. Toxicol Sci. 75(2): 41222.

Deepak A; Rao LT and Bhushan V (2008):

First aid for the Usmle step 1. Mc. Graw-Hill Medical. USA.

Drury R AV and Wallington E

A (1980):

Carltons Histological

Techniques Oxford
University Press, New York. Pronto. P: 206:225.

Duru M; Nacar A; Yonden Z; Kuvandik M R; Koc A; Akaydin Y; Oksuz H and Sogut $S$ (2008):

Protective Effect of $\mathrm{N}$ acetylcysteine on Cyclosporine A-induced Nephrotoxicity. Ren. Fail. 30(4): 453-9.

FAO/WHO (2002):

Human vitamin and mineral requirements. Report of a joint FAO/WHO consultation, Bangkok, Thailand. Food and Agriculture Organization of the United Nations (FAO), Rome, Italy

Fatima S; Arivarasu NA and Mahmood R (2007):

Vitamin $\mathrm{C}$ attenuates cisplatin-induced

alterations in renal brush border membrane enzymes and phosphate transport. Hum Exp Toxicol. 26: 419-426. 
Frank D; Larry K and Joseph A (2008):

Nitric Oxide Reacts With Methoxide. J. Org. Chern. 73: 1139 - 1142.

Gandhi UH; Nagaraja TP and Prabhu SK (2013):

Selenoproteins and their role in oxidative stress and inflammation. Curr Chem Biol. 7:65-73.

Gross JL; Azevedo, MJ; Silveiro SP; Canani, L.H.; Caramori ML and Zelmanovitz, T (2005):

Diabetic Nephropathy: Diagnosis, prevention and treatment. Diabetes Care. 28 (1): 164-76.

Hosoya N (1980):

Nutrition Experiments Using Small Animals. Tokyo: Daiichi Shuppan. Japanese. P.71.

Irmants J; Yoav S; Stefan K; et al., (2004):

Effect of aldosterone on Renal Transforming Growth Factor B. Am. J.
Physiol. Real. Physiol. 286: F1059-F1062.

Janebova $M$ and Zima $T$ (1997):

Methods for determination of vitamins $A$ and $E$ our Simple HPLC Assay. Sbomik Lekarsky. 98(3):195-208.

Khan SA; Priyamvada S and Farooq N (2009):

Protective Effect of Green Tea Extract on Gentamlcm-Induced Nephrotoxicity and Oxidative Damage in Rat Kidney. Pharmacol Res. 59(4): 254-62.

Kurtz N R (1983):

Introduction to Social Statistics. Mc Grow-Hill Book Company. New York. P.163.

Lambert JD and Elias RJ (2010):

The antioxidant and prooxidant activities of green tea polyphenols: a role in cancer prevention. Arch 
Physiological effect of Selenium\& Green tea treatment on Cisplatin-induced

Biochem

Biophys. 501:65-72.

Macfarquhar JK; Broussard DL and Melstrom $P$ (2010):

Acute Selenium Toxicity Associated With A

Dietary Supplemented. Arch. Intern. Med. 170 (3): 256-61.

Miller RP; Tadagavadi RK; Ramesh G and Reeves WB (2010):

Mechanisms of cisplatin nephrotoxicity. Toxins. 2(11):2490-518.

Mohamadin AM; EIBeshbishy HA and EIMahdy MA (2005): GreenTea Extract Attenuates Cyclosporine A-Induced Oxidative Stress in Rats. Pharmacol. Res. 5 Jan.51 (1): 51-7.

Montgomery HA and Dymock JF (1961):

The determination of nitrate in water. Analyst, 86,414-416.
Pompella A; Visvikis A; Paolicchi A; Detata V and Casini AF (2003): The Changing Faces of Glutathione, A Cellulat Protagonist. Biochem. Pharmacol. 66 (8): 1499503.

Reeves P G; Nielsen F $\mathbf{H}$ and Fahey G C (1993):

Ain-93 Purified Diet or Laboratory Rodents: Final report of the American Institute of Nutrition. Ad Hoc Writing. Committee on the Reformulation of the Ain-76-A Rodent Diet. 1. Nutr. 123:1939-1951

Saad SY; Arafah MM and Najjar T A (2007):

Effect of Mycophenolate Mofetil on CisplatinInduced Renal Dysfunction in Rats. Cancer Chemother Phermacol.59(4):455-60.

Saravanan N and Nalini N (2007):

Impact of Hemidesmus Indicus R.Br. Extract on ethanolmediated 
oxidative damage in rat kidney. Redox. Rep. 12 (5): 229-35.

Scalbert A and Wiliams G (2005):

Dietary intake and Bioavailablity of Polyphenols. J. Nutr. 2073-85.

Staci Nix MS RD. (2005):

Basic Nutrition Diet Therapy. Twelfth

Edition. Elsevier Mosby, Inc. USA.

Stojiljkovic N; Veljkovic S and

Mihailovic (2009):

Protective effect of Pentoxifylline treatment on Gentamicin-Induced Nephrotoxicity in rats. Ren. Fail. 31(1): 54-61.

Sunderman FW Jr and Sunderman FW (1958):

Serum electrolytes. A rapid, reliable method for serum Potassium. Am. J. Clin. Pathol. 29: 95.

Tietz NW (1986):

Textbook of Clinical Chemistry.
Saunders, Ph, pp12711281.

Tietz NW (1990):

Clinical Guide to Laboratory tests. 2nd ed.Philadelphia. WB Saunders. 566.

Tietz NW (1994):

Clinical Chemistry.2nd ed.W.B. Saunders, Philadelphia, JAMA.272 (8):644-645.

Trinder P (1951):

A rapid method for Sodium in serum. Analyst. 76: 596-599.

Tsao R (2010):

Chemistry and biochemistry of dietary polyphenols. Nutrients. 2:1231-1246.

Veljković M; Pavlović DR; Stojiljković N; Ilić S; Petrović

A; Jovanović I and Radenković M (2016): Morphological and morphometric study of protective effect of green tea in gentamicin- 
Hewaida A.E.Fadel

induced nephrotoxicity in rats. Life Sci.147:85-91.

Wang H; Zhang $\mathrm{J}$ and $\mathrm{Yu} \mathrm{H}$ (2007):

Elemental Selenium at

Nano size possesses lower toxicity without compromising the fundamental effect on Selenoenzymes: comparison with Selenomethionine in mice. Free Radic. BioI. Med. 42 (10): 1524-33.

Yanardag R; Ozsoy $O$ and Ozdil S (2007):

Combined effects of vitamin $\mathrm{C}$, vitamin $\mathrm{E}$ and Sodium Selenate supplementation on absolute ethanol-induced injury in various organs of rats. IntJ.Toxicoi. 26 (6): 513-23.

Yi A; Xin H; Yan W and Zhou $X$ (2011):
Amelioration of cisplatin-induced nephrotoxicity by pravastatin in mice. ExpToxicol Pathol. 63:21-59.

Yokozawa $T$; Nakagawa $T$ and Oya T (2005):

Green tea polyphenols and dietary fiber Orotect against kidney damage in rats with Diabetic Nephropathy. J. Pharm Pharmacol. 57 (6):77380.

\section{Zhang J; Wang $X$ and XuT} (2008):

Elemental Selenium at Nano Size (Nano-Se) potential chemo preventive agent with reduced risk of Selenium toxicity: comparison with Se-methylselenocyteine in mice. Toxico. Sci. 101(1):22-31. 
TABLE (1): Effect of Selenium and Green Tea Treatment on Food Intake, Body Weight Gain and Food Efficiency Ratio in the Studied Groups of Rats

\begin{tabular}{|c|c|c|c|c|c|}
\hline \multicolumn{2}{|c|}{ Groups } & \multirow{2}{*}{$\begin{array}{c}\begin{array}{c}\text { Negative } \\
\text { control }\end{array} \\
\begin{array}{c}9.36 \pm \\
011^{\mathrm{a}}\end{array}\end{array}$} & \multirow{2}{*}{$\begin{array}{c}\begin{array}{c}\text { Positive } \\
\text { control } \\
\text { (Nephrotoxic) }\end{array} \\
7.21 \pm \\
0.11^{\mathrm{c}}\end{array}$} & \multirow{2}{*}{$\begin{array}{c}\text { Selenium } \\
2.43 \pm \\
0.11^{\mathrm{d}}\end{array}$} & \multirow{2}{*}{$\begin{array}{c}\begin{array}{c}\text { Green } \\
\text { Tea }\end{array} \\
8.54 \pm \\
0.10^{\mathrm{b}}\end{array}$} \\
\hline हิ & Mean $\pm S$ D & & & & \\
\hline 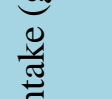 & $\begin{array}{l}\text { \% change from } \\
\text { control }\end{array}$ & - & -22.98 & -73.97 & -8.72 \\
\hline 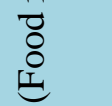 & $\begin{array}{l}\% \text { change from } \\
\text { nephropathy }\end{array}$ & - & - & -66.20 & 18.50 \\
\hline \multirow{3}{*}{ 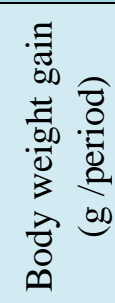 } & Mean \pm SD & $\begin{array}{l}18.25 \pm \\
0.70^{b}\end{array}$ & $\begin{array}{l}1.27 \pm \\
0.07^{\mathrm{f}}\end{array}$ & $\begin{array}{l}1.72 \pm \\
0.08^{f}\end{array}$ & $\begin{array}{l}14.5 \pm \\
0.92^{c}\end{array}$ \\
\hline & $\begin{array}{l}\% \text { change from } \\
\text { Control }\end{array}$ & - & -93.01 & -90.54 & -20.54 \\
\hline & $\begin{array}{l}\text { \% change from } \\
\text { nephropathy }\end{array}$ & - & - & 35.92 & 1037.2 \\
\hline \multirow{3}{*}{ 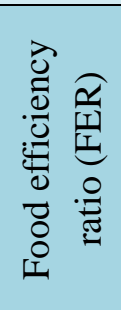 } & Mean \pm SD & $\begin{array}{c}0.06 \pm \\
0.003^{b}\end{array}$ & $\begin{array}{l}0.006 \pm \\
0.0003^{\mathrm{f}}\end{array}$ & $\begin{array}{c}0.02 \pm \\
0.002^{\mathrm{e}}\end{array}$ & $\begin{array}{l}0.06 \pm \\
0.003^{c}\end{array}$ \\
\hline & $\begin{array}{l}\% \text { change from } \\
\text { Control }\end{array}$ & - & -90.92 & -63.57 & -12.94 \\
\hline & $\begin{array}{l}\text { \% change from } \\
\text { Nephropathy }\end{array}$ & - & - & 301.53 & 859.75 \\
\hline
\end{tabular}

The values which had different letters were statistically significant at $(\mathrm{P}<0.05)$

No significant difference between the values had the same letter in row. 
Physiological effect of Selenium\& Green tea treatment on Cisplatin-induced Nephrotoxicity in Rats

Hewaida A.E.Fadel

TABLE (2): Effect of Selenium and Green Tea Treatment on Serum

Vitamin E Concentration and Kidney Glutathione Content in the

Studied Groups of Rats

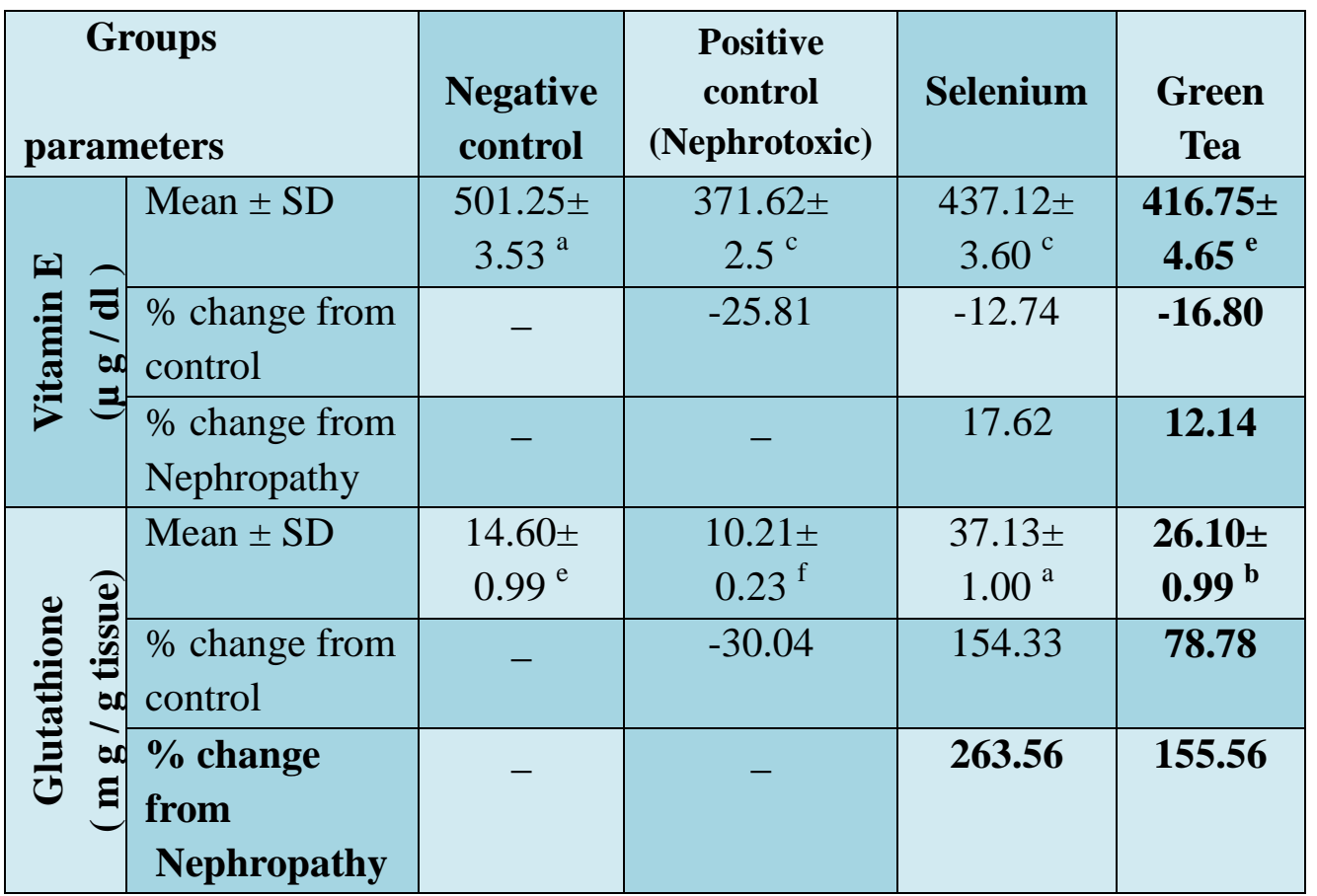

The values which had different letters were statistically significant at $(\mathrm{P}<0.05)$

No significant difference between the values had the same letter in row. 
Physiological effect of Selenium\& Green tea treatment on Cisplatin-induced Nephrotoxicity in Rats

Hewaida A.E.Fadel

TABLE (3): Effect of Selenium and Green Tea Treatment on Kidney Function in the Studied Groups of Rats

\begin{tabular}{|c|c|c|c|c|c|}
\hline \multicolumn{2}{|c|}{\begin{tabular}{|} 
Groups \\
parameters
\end{tabular}} & \multirow{2}{*}{$\begin{array}{l}\begin{array}{l}\text { Negative } \\
\text { control }\end{array} \\
26.51 \pm \\
0.88^{\mathrm{f}}\end{array}$} & \multirow{2}{*}{$\begin{array}{l}\begin{array}{l}\text { Positive } \\
\text { control } \\
\text { (Nephrotoxic) }\end{array} \\
69.68 \pm \\
0.72^{\mathrm{a}}\end{array}$} & \multirow{2}{*}{$\begin{array}{l}\text { Selenium } \\
35.88 \pm \\
0.83^{b}\end{array}$} & \multirow{2}{*}{$\begin{array}{l}\text { Green } \\
\text { Tea } \\
31.71 \pm \\
0.87^{d}\end{array}$} \\
\hline \multirow{3}{*}{ 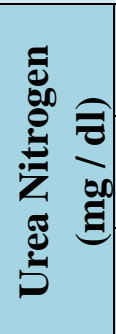 } & Mean \pm SD & & & & \\
\hline & $\begin{array}{l}\% \text { change from } \\
\text { control }\end{array}$ & - & 162.84 & 35.36 & 19.61 \\
\hline & $\begin{array}{l}\% \text { change from } \\
\text { Nephropathy }\end{array}$ & - & - & -48.50 & -54.49 \\
\hline \multirow{3}{*}{ 昰 } & Mean \pm SD & $\begin{array}{l}0.64 \pm \\
0.01^{d}\end{array}$ & $\begin{array}{l}2.05 \pm \\
0.14^{\mathrm{a}}\end{array}$ & $\begin{array}{l}0.92 \pm \\
0.03^{b}\end{array}$ & $\begin{array}{l}0.91 \pm \\
0.04^{b}\end{array}$ \\
\hline & $\begin{array}{l}\% \text { change from } \\
\text { Control }\end{array}$ & - & 217.21 & 42.74 & 41.01 \\
\hline & $\begin{array}{l}\% \text { change from } \\
\text { Nephropathy }\end{array}$ & - & - & -55.0 & -55.54 \\
\hline \multirow{3}{*}{ 胥 } & Mean \pm SD & $\begin{array}{l}1.125^{ \pm} \\
0.07^{\mathrm{d}}\end{array}$ & $\begin{array}{r}2.16 \pm \\
0.09^{\mathrm{a}} \\
\end{array}$ & $\begin{array}{l}1.58 \pm \\
0.12^{\mathrm{b}}\end{array}$ & $\begin{array}{l}1.5 \pm \\
0.13^{b c}\end{array}$ \\
\hline & $\begin{array}{l}\% \text { change from } \\
\text { control }\end{array}$ & - & 92.22 & 41.11 & 33.33 \\
\hline & $\begin{array}{l}\text { \% change from } \\
\text { Nephropathy }\end{array}$ & - & - & -26.58 & -30.63 \\
\hline \multirow{3}{*}{ 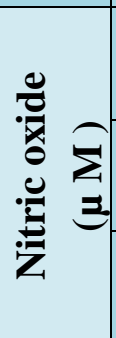 } & Mean \pm SD & $\begin{array}{l}12.82 \pm \\
0.48^{\mathrm{f}}\end{array}$ & $\begin{array}{l}28.02 \pm \\
0.31^{\mathrm{a}}\end{array}$ & $\begin{array}{l}17.4 \pm \\
0.51^{\mathrm{b}}\end{array}$ & $\begin{array}{l}15.2 \pm \\
0.47 \text { D }\end{array}$ \\
\hline & $\begin{array}{l}\% \text { change from } \\
\text { control }\end{array}$ & - & 118.51 & 35.67 & 18.51 \\
\hline & $\begin{array}{l}\text { \% change from } \\
\text { Nephropathy }\end{array}$ & - & - & -37.91 & -45.76 \\
\hline
\end{tabular}

The values which had different letters were statistically significant at $(\mathrm{P}<0.05)$

No significant difference between the values had the same letter in row. 
Physiological effect of Selenium\& Green tea treatment on Cisplatin-induced Nephrotoxicity in Rats

Hewaida A.E.Fadel

TABLE (4): Effect of Selenium, and Green Tea Treatment on Serum Sodium, Potassium and Total Protein and Albumin on the Studied Groups of Rats

\begin{tabular}{|c|c|c|c|c|c|}
\hline 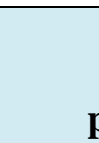 & $\begin{array}{l}\text { Groups } \\
\text { ameters }\end{array}$ & $\begin{array}{l}\text { Negative } \\
\text { control }\end{array}$ & $\begin{array}{l}\text { Positive } \\
\text { control } \\
\text { (Nephrotoxic) }\end{array}$ & Selenium & $\begin{array}{l}\text { Green } \\
\text { Tea }\end{array}$ \\
\hline \multirow{3}{*}{ 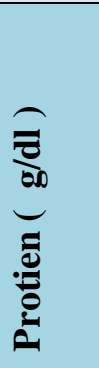 } & Mean \pm SD & $\begin{array}{l}7.48 \pm \\
0.11^{\mathrm{f}}\end{array}$ & $\begin{array}{l}4.33 \pm \\
0.13^{a}\end{array}$ & $\begin{array}{l}6.25 \pm \\
0.16^{b}\end{array}$ & $\begin{array}{l}6.3 \pm \\
0.16^{c}\end{array}$ \\
\hline & $\begin{array}{l}\text { \% change } \\
\text { from } \\
\text { control }\end{array}$ & - & -42.07 & -16.52 & -15.85 \\
\hline & $\begin{array}{l}\text { \% change } \\
\text { from } \\
\text { Nephropathy }\end{array}$ & - & - & 44.09 & 45.24 \\
\hline \multirow{3}{*}{ 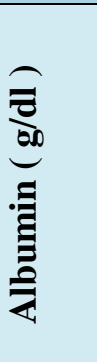 } & Mean \pm SD & $\begin{array}{l}3.78 \pm \\
0.17^{\mathrm{a}}\end{array}$ & $\begin{array}{l}1.75 \pm \\
0.13^{b}\end{array}$ & $\begin{array}{l}2.73 \pm \\
0.13^{c}\end{array}$ & $\begin{array}{l}2.91 \pm \\
0.18^{c}\end{array}$ \\
\hline & $\begin{array}{l}\text { \% change } \\
\text { from } \\
\text { Control }\end{array}$ & - & -53.79 & -27.72 & -23.10 \\
\hline & $\begin{array}{l}\text { \% change } \\
\text { from } \\
\text { Nephropathy }\end{array}$ & - & - & 56.42 & 66.42 \\
\hline \multirow{3}{*}{ 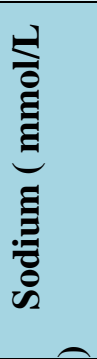 } & Mean \pm SD & $\begin{array}{l}141.76 \pm \\
0.73^{\mathrm{f}}\end{array}$ & $\begin{array}{l}199.16 \pm \\
1.96^{\mathrm{a}}\end{array}$ & $\begin{array}{l}158.15 \pm \\
0.95^{b}\end{array}$ & $\begin{array}{l}149.45 \pm \\
0.76^{c}\end{array}$ \\
\hline & $\begin{array}{l}\% \text { change } \\
\text { from } \\
\text { control }\end{array}$ & - & 40.49 & 11.55 & 5.42 \\
\hline & $\begin{array}{l}\text { \% change } \\
\text { from } \\
\text { Nephropathy }\end{array}$ & - & - & -20.59 & -24.96 \\
\hline \multirow{3}{*}{ 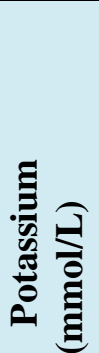 } & Mean \pm SD & $\begin{array}{l}5.11 \pm \\
0.26^{\mathrm{a}} \\
\end{array}$ & $\begin{array}{l}3.86 \pm \\
0.31^{d} \\
\end{array}$ & $\begin{array}{l}4.27 \pm \\
0.28^{c} \\
\end{array}$ & $\begin{array}{l}4.37 \pm \\
0.16^{c} \\
\end{array}$ \\
\hline & $\begin{array}{l}\text { \% change } \\
\text { from } \\
\text { control }\end{array}$ & - & -24.44 & -16.38 & -14.42 \\
\hline & $\begin{array}{l}\text { \% change } \\
\text { from } \\
\text { Nephropathy }\end{array}$ & - & - & 10.67 & 13.26 \\
\hline
\end{tabular}

The values which had different letters were statistically significant at $(\mathrm{P}<0.05)$

No significant difference between the values had the same letter in row. 


\begin{tabular}{|c|c|}
\hline $\begin{array}{r}\text { Photo (1): Kidney of rat from negative c } \\
\text { structure of renal }\end{array}$ & $\begin{array}{l}\text { rol group showing the normal histological } \\
\text { nchyma.(H\&Ex200) }\end{array}$ \\
\hline $\begin{array}{l}\text { Photo (2): Kidney of rat from } \\
\text { nephrotoxic group showing Vacuolations } \\
\text { of epithelial lining renal tubules in the } \\
\text { renal cortex. (H\& Ex 200) }\end{array}$ & $\begin{array}{l}\text { Photo (3): Kidney of rat from nephrotoxic } \\
\text { group showing presence of eosinophilic } \\
\text { protein cast in the lumen of renal tubules } \\
\text { and per tubular leukocyte cell infiltration. } \\
\text { (H\& Ex 200) }\end{array}$ \\
\hline $\begin{array}{l}\text { Photo (4): Kidney of rat from Selenium } \\
\text { group showing no histopathological } \\
\text { changes.(H\&Ex200) }\end{array}$ & $\begin{array}{l}\text { Photo (5): Kidney of rat from Selenium } \\
\text { group showing no histopathological } \\
\text { changes. (H\& Ex 200) }\end{array}$ \\
\hline $\begin{array}{l}\text { Fig.(7): Kidney of rat from green tea } \\
\text { group showing protein cast in the lumen } \\
\text { of some renal tubules\& few per tubular } \\
\text { leukocyte cells infiltration .(H\&Ex } 200)\end{array}$ & $\begin{array}{l}\text { Fig.(6): Kidney of rat from green tea group } \\
\text { showing normal renal parenchyma. } \\
\text { (H\&Ex200) }\end{array}$ \\
\hline
\end{tabular}




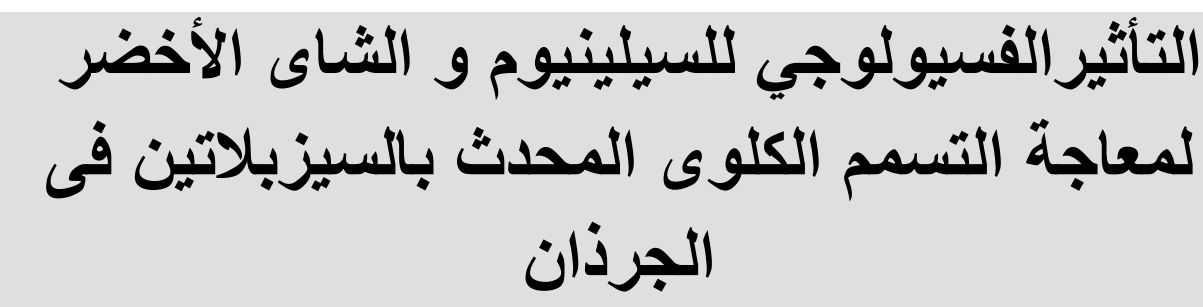

هويدا عبد الفتاح السبد فاضل

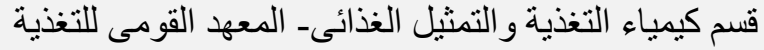

تهُف هذه الدراسة الى اختبار فاعلية تناول السلينبيوم و الشاى الأخضر كمضادات للأكسدة

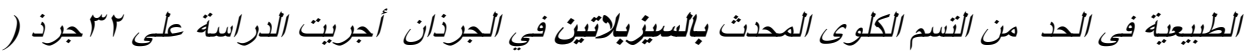

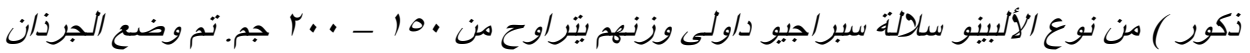

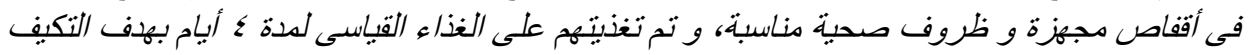

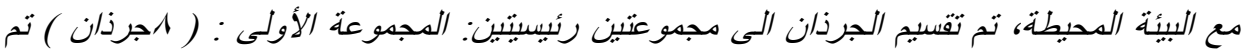

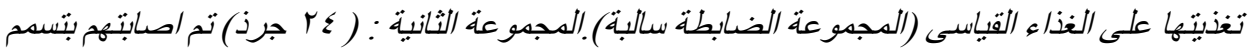

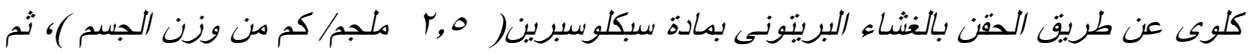

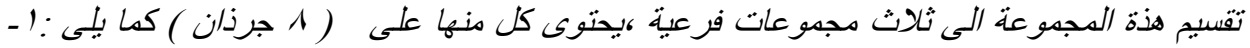

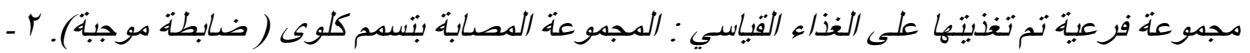

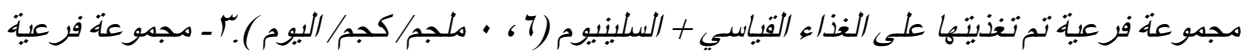

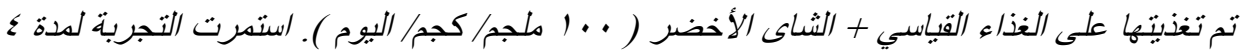

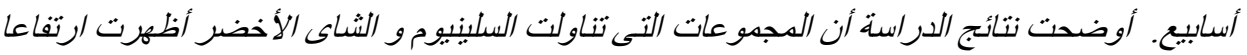

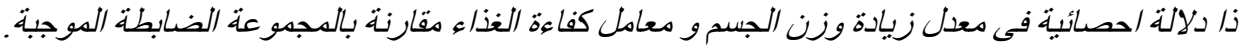

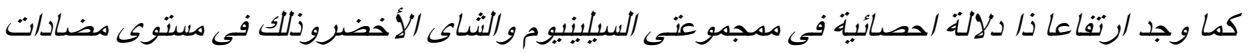

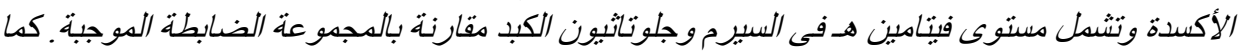

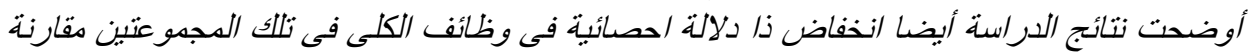

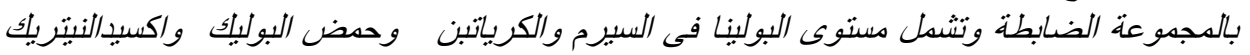

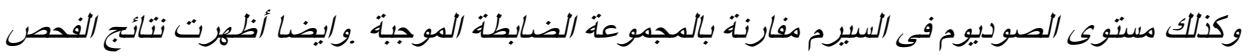

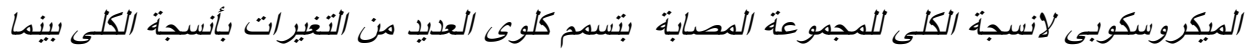

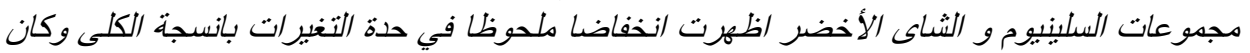

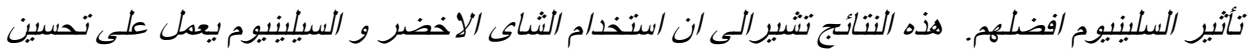
وظائف الكبد فى الفئر ان المصابة بتسمم كلوى.

الكلمات المفتاحية: السلينبيوم- الثاى الأخضر - مضاد/ت أكسدة طبيعية- السبزبلاتبن- التسدم الكلوى وظائف الكبب. 